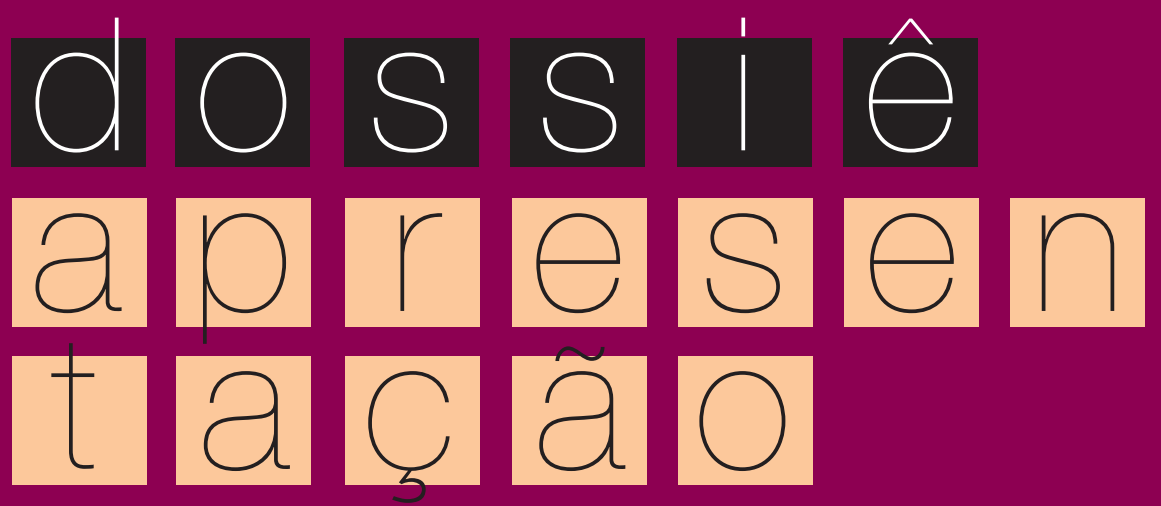


Uma homenagem a Geneviève Jacquinot-Delaunay.

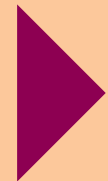




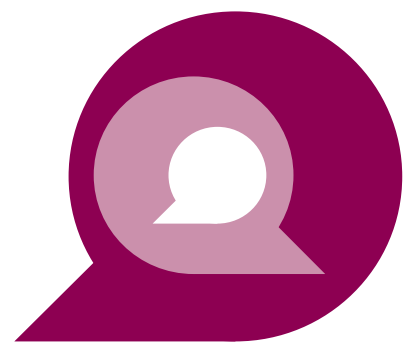

\section{Nos ombros de gigantes: uma homenagem a Geneviève Jacquinot-Delaunay}

LIA RAQUEL DE OLIVEIRA *

ROSA MARIA CARDOSO DALLA COSTA **

A revista Ação Midiática apresenta neste número um dossiê especial composto pela tradução de 12 textos publicados no número 8 da revista francesa Distances et Médiations du Savoir, de dezembro de 2014, dedicado à professora e pesquisadora francesa Geneviève Jacquinot-Delaunay. A proposta e a tradução destes textos tem como objetivo principal tornar mais conhecido, em língua portuguesa, o pensamento desta que foi uma das pioneiras no estudo da relação entre comunicação, tecnologia e educação, ainda em meados do século vinte.

Distances et Médiations du Savoir faz mais do que homenagear Jacquinot, ao compor um número inspirado nela, com textos de diversos pesquisadores franceses que tratam o tema - a EaD - relacionando seus próprios objetos investigativos com os textos da autora, questionando-os algumas vezes, propondo reflexões e atualizações de sua obra.

* Professora Universidade do Minho, Portugal.

** Professora Associada da Universidade Federal do Paraná (UFPR), Brasil. 
Poderia esta tradução ter um subtítulo para além do simples traduzido: On demandera toujours des inventeurs qui gardent la trace de leurs prédécesseurs -inspirado em Jacquinot $(1977,1981)$ e Tardy (1966), ou seja, precisamos sempre de inventores que caminhem nos ombros dos seus predecessores. Os gigantes costumam baixar os ombros para se aproximarem dos outros, mas continuam sendo grandes e olhando mais longe.

Dizia Christian Metz - orientador de tese de doutorado de Jacquinot - no prefácio à obra Image et Pédagogie: "Um movimento científico não vive das suas aplicações, mas das suas evoluções; não dos seus 'discípulos', mas dos seus continuadores" (in JACQUINOTDELAUNAY, 2006a, p. 10). Atrevemo-nos a esse desafio.

Ao longo do século XX, toda a novidade tecnológica ligada à comunicação acabou por ser aplicada à educação, acompanhada por discursos bastante apaixonados sobre a modernização, a inovação e a mudança de paradigma (expressão habitualmente aplicada no sentido corrente de modelo).

Um media empurra o outro e cada novo gadget constitui ocasião para recolocar a pseudo-questão fundamental: "O media X vai transformar o ensino?" As respostas reduzem-se todas, ou quase todas, a uma defesa ou ilustração da máquina em questão: esta é apresentada pelo tecnólogo como útil, e o seu uso educativo, na melhor das hipóteses, é postulada em termos de objetivo da sociedade. A gama de meios disponíveis testemunha a paixão pela inovação que caracteriza a educação hoje. E, contudo... precisamos sempre de inventores. (JACQUINOT, 1981, p. 5).

Não se esgota aqui a pertinência e clareza do pensamento da autora. São os seus múltiplos, clarividentes e sóbrios insights que o justificam.

Esta proposta de tradução resulta do fato de ambas - uma professora portuguesa e outra brasileira - termos trabalhado de perto com Geneviève Jacquinot-Delaunay e de termos sido suas doutorandas, na Universidade de Vincennes, Paris 8. O que pudemos com ela aprender ultrapassa os limites de um trabalho desta natureza, mas a difusão da sua obra parece-nos da maior importância e mesmo urgência. Os autores traduzidos discutem na atualidade os conceitos introduzidos por Geneviève Jacquinot-Delaunay. Concordam, questionam, problematizam: avançam no conhecimento. 
Escolher uma pedagogia não é somente definir uma forma local de intervenção, é situar-se na sociedade e na cultura, é, implícita ou explicitamente, tomar posição, fazer escolhas. Os problemas pedagógicos, como os outros, são, num determinado nível de análise, problemas políticos. (JACQUINOT-DELAUNAY, 2006a [1977], p. 32)

Jacquinot-Delaunay sempre foi provocativa, como sugere o número especial da revista francesa cujos textos apresentamos aqui em língua portuguesa. Sempre esteve adiante do seu tempo e sempre se inquietou com as mudanças que as tecnologias do século vinte introduziram na sociedade:

há uma real impostura ao sustentar-se que o audiovisual [leia-se digital, por exemplo, no lugar de audiovisual, nota das autoras] - como se diz - é um fator "de inovação", de "renovação" ou de "revolução" no ensino quando, na realidade, serve, na maioria das vezes, para reforçar os modelos pedagógicos mais tradicionais. A modernidade dos suportes não garante nada. Porque o medium é uma variável entre muitos outros no processo educativo; porque a ferramenta em si mesmo não conduz a nada, senão a uma possibilidade de mudança (idem, p.123).

Formada em Estudos Literários, Jacquinot-Delaunay iniciou no magistério como professora de francês e literatura em uma classe de ensino fundamental, da escola pública francesa, na década de 1960. Foi quando percebeu que seus alunos "estavam em outro planeta", como disse em entrevista à revista Comunicação \& Educação (2007, p. 73-80). Foi então participar de um concurso promovido pela Televisão Escolar e, ao vencer, começou a trabalhar nas funções de educadora e de autora-criadora de cenários pedagógicos em programas televisivos (DALLA COSTA, 2007, p. 73-74).

Essa experiência a motivou a fazer o doutorado, sob a orientação do professor Christian Metz, na Escola de Hautes Etudes em Sciences Sociales. Em seguida, em 1969, foi convidada para dar aulas no Departamento de Ciências da Educação, pela equipe fundadora da nova Universidade Paris 8 - Vincennes, criada em decorrência dos acontecimentos de maio de 1968. Ali trabalhou a interface comunicação-educação, questionando metodologias e propondo análises sobre a utilização da tecnologia na escola. Orientou teses em Ciências da Educação 
e, a partir dos anos de 1995, em Ciências da Informação e da Comunicação. Dialogava perfeitamente nas duas áreas (cf. JACQUINOT-DEALUNAY, 2006b) e, como ninguém, sabia como relacioná-las.

Seu interesse pela tecnologia a levou a pesquisar também o ensino a distância, sobretudo no que diz respeito à mediação pedagógica. Escreveu inúmeros artigos e livros a respeito, como o texto Ausência e presença na mediação pedagógica: "Rien ne vaut la chaleur de la présence humaine" (JACQUINOT-DELAUNAY, 2002) que inspirou uma de nós a afirmar:

a distância transacional não é exclusiva do ensino a distância; ela existe em todos os relacionamentos humanos e, por via de uma praxis histórica de centenas de anos, revela-se particularmente na sala de aula. Na sala de aula presencial (basta lembrar a aula magistral em auditório) e na sala de aula virtual (palestra em videoconferência síncrona ou assíncrona) (OLIVEIRA, 2015, p. 174).

Seu objetivo era o de compreender como a partir das tecnologias cada vez mais presentes na sociedade, se pode melhorar ou aprimorar o processo de aprendizagem, como evidencia em sua afirmação:

assim, à questão de se saber se este ou aquele meio é mais eficaz do que um outro, conviria substituir a seguinte questão: que atributos específicos de que medium são próprios para favorecer que processo de aprendizagem em função de que traços característicos do aluno e tendo em consideração a tarefa a cumprir. Investigações como estas começam apenas agora a fazer-se (JACQUINOT-DELAUNAY, 2006a [1977], p.125).

Jacquinot-Delaunay morreu em dezembro de 2014, em plena atividade acadêmica e deixando órfãos cerca de vinte professores-pesquisadores, ex-orientandos seus. Deixou também um vazio no meio intelectual francês que a ela se referia como uma verdadeira dama da Ciência da Educação. Aberta ao novo, ao conhecimento, sobretudo, sempre se dispôs a viajar e a escrever em conjunto com seus orientandos e colegas. Fazia na prática o que seu legado teórico tão bem expressa:

o modelo didático tradicional faz do ato didáctico um ato de transmissão de um saber constituído de alguém que sabe, em direção a alguém que não sabe, segundo um itinerário estreitamente baliza- 
do. A imagem, e nomeadamente a imagem fílmica, é particularmente adequada para servir um outro modelo didáctico - gerativo e já não estrutural - o que faz do ato didáctico um processo de produção de sentido (idem, p. 18).

Os textos aqui apresentados tratam especificamente da educação a distância. E, em cada um deles, o autor associa suas próprias pesquisas a escritos de Jacquinot-Delaunay sobre o tema, o que nos permite uma reflexão aprofundada sobre o conceito de distância, as metodologias utilizadas e mesmo a representação que os alunos dessa modalidade de ensino têm da formação que recebem. No Editorial de Martine Vidal, Monique Grandbastien e Pierre Moeglin encontram-se especificadas estas abordagens. A leitura de cada um deles certamente propiciará inquietações naqueles que, como ela, entendem que é preciso questionar o uso das tecnologias na educação. $\mathrm{O}$ que significa dizer, que Jacquinot-Delaunay, através de seus textos, continua fazendo o que sempre fez para produzir conhecimento: provocar! Fica a sua presença e o seu saber transmitido, sempre em busca de novas invenções.

\section{REFERÊNCIAS}

DALLA COSTA, Rosa Maria Cardoso. Entrevista com Geneviève Jacquinot Delaunay. Revista Comunicação \& Educação. São Paulo: ECA-USP. Ano 12, n. 3 (set - dez. 2007), p. 73-80.

JACQUINOT-DELAUNAY, Geneviève. Entrevista à revista Comunicação \& Educação. São Paulo: ECA-USP. Ano 12, n. 3 (set - dez. 2007), p. 73-80.

JACQUINOT-DELAUNAY, Geneviève. Imagem e Pedagogia. Mangualde: Edições Pedago, 2006a. Tradução e Revisão Científica por Lia Oliveira. Original: Jacquinot, G. Image et Pédagogie. Paris: PUF, 1977.

JACQUINOT-DELAUNAY, Geneviève. As Ciências da Educação e as Ciências da Comunicação em Diálogo: a propósito dos media e das tecnologias educativas, 2006b. In J. PARASKEVA \& L. R. OLIVEIRA (Orgs.) Currículo e Tecnologia Educativa. volume 1. Mangualde: Edições Pedago. p. 123-141. Texto original em francês Disponível em https://www.cairn.info/revue-l-annee-sociologique-20012-page-391.htm. Acesso em 21 de novembro de 2016. 
JACQUINOT-DELAUNAY, Geneviève. Absence et présence dans la médiation pédagogique ou comment faire circuler les signes de la présence. In: COOL, R. Guir. (ss dir de). Pédagogies en développement. Pratiquer les TICE, Former les enseignants et les formateurs à de nouveaux usages. Bruxelles: De Boeck. 2002. s/p.

JACQUINOT, Geneviève. On demande toujours des inventeurs,

Communications, 33, p. 5-23,1981. DOI: 10.3406/comm.1981.1492

JACQUINOT, Geneviève. Apprivoiser la distance et supprimer l'absence? Ou les défis de la formation à distance. Revue Française de Pédagogie, 102, janvierfévrier-mars. 1993. p. 55-67.

OLIVEIRA, Lia Raquel (2015). Rien ne vaut la chaleur de la présence humaine: encurtando a distância transacional. Educativa, Goiânia, v.18, n. 1 (2015) p. 168 188 Disponível em: http://dx.doi.org/10.18224/educ.v18.n1.2015.168-188.

OLIVEIRA, Lia Raquel. Mediação docente e distância transacional: uso do Facebook num mestrado em regime misto (b-learning). Texto apresentado oralmente no congresso ENDIPE 2016 e em fase de submissão a uma revista.

TARDY, Michel. Le professeur et les images. Paris: PUF, 1966. Edição em língua portuguesa: O Professor e as Imagens, 1976, Cultrix. 


\section{Standing on the shoulders of giants: a tribute to Geneviève Jacquinot-Delaunay}

LIA RAQUEL DE OLIVEIRA *

ROSA MARIA CARDOSO DALLA COSTA **

This edition of Ação Midiática journal presents a special dossier composed of the translation of twelve writings previously published in December 2014 in the $8^{\text {th }}$ issue of the French journal Distances et Médiations du Savoir, which was dedicated to the French teacher and researcher Geneviève Jacquinot-Delaunay. The proposal for translating these writings is to make known, in Portuguese, the thoughts from one of the twentieth century pioneers in the study of the relations between communication, technology and education.

Distances et Médiations du Savoir not only pays tribute to Jacquinot through the publication of an issue inspired by her, but it also questions, promotes reflections and updates of her work through French researchers' writings that deal with the theme (the Distance Learning) and relate their own investigative objects with Jacquinot's texts.

This translation could have a subheading that went beyond a mere translation inspired by Jacquinot $(1977,1981)$ and Tardy

* Professor at the Universidade do Minho, Portugal.

** Professor at the Universidade Federal do Paraná (UFPR), Brazil. 
(1966); On demandera toujours des inventeurs qui gardent la trace de leurs prédécesseurs. In other words, we will always need inventors that stand on the shoulders of their predecessors. Giants usually lower their shoulders to get closer to the others, but they are still tall and keep looking further ahead.

Christian Metz who was Jacquinot's Doctoral advisor stated the following at the preface of the work Image et Pédagogie: "A scientific movement does not live for its applications, but for its evolutions; not those of its disciples, but of its followers" (in JACQUINOT-DELAUNAY, 2006a, p. 10). We accept this challenge.

Throughout the 20th century, every new technological device related to communication was applied to education and followed by passionate speeches about the modernization, the innovation and the changes of a paradigm (an expression that usually has the sense of a current model).

One media pushes another and every new gadget provides the occasion to bring back a fundamental pseudo-question: "Will media $\mathrm{X}$ change education?" All or almost all the answers are reduced to the defense or the illustration of the machine in question: it is presented by the technologist as useful, and in the best-case scenario its educational use is postulated in terms of society's goal. The range of available media testifies the passion for innovation that characterizes the education nowadays. And, yet... we always need inventors ${ }^{1}$ (JACQUINOT, 1981, p. 5).

The relevance and clearness of the authors' thoughts does not end here. Her multiple, clairvoyant and sober insights justify them.

This translation proposal results from the fact that both a Portuguese and a Brazilian teachers had worked close with Geneviève Jacquinot-Delaunay. In addition, they both had been her $\mathrm{PhD}$ advisees at the University of Vincennes, Paris 8 . What we were able to learn surpasses the limitations in this nature of work, but its diffusion seems to be of greater importance, and even urgency. The translated authors bring concepts first introduced by Geneviève Jacquinot-De-

1 Original: Um media empurra o outro e cada novo gadget constitui ocasião para recolocar a pseudo-questão fundamental: "O media X vai transformar o ensino?" As respostas reduzem-se todas, ou quase todas, a uma defesa ou ilustração da máquina em questão: esta é apresentada pelo tecnólogo como útil, e o seu uso educativo, na melhor das hipóteses, é postulada em termos de objetivo da sociedade. A gama de meios disponíveis testemunha a paixão pela inovação que caracteriza a educação hoje. E, contudo... precisamos sempre de inventores. 
launay to an up-to-date discussion. They agree, question, problematize: they promote the advancement of knowledge.

Choosing a pedagogy is not only to define a local model of intervention, it is also to situate oneself in society and culture, it is to take position and to make choices whether implicitly or explicitly. The pedagogical problems, just like others, are in a given level of analysis, political problems ${ }^{2}$ (Jacquinot-Delaunay, 2006a [1977], p. 32).

Jacquinot-Delaunay was always provocative, as suggests the special issue of the French journal that we present in Portuguese here. She was always ahead of her time and concerned with changes that had been introduced in society by the twentieth century technologies:

There is a real imposture on sustaining that audiovisual [for instance, read digital instead of audiovisual, authors' note] - as it is said - it is a factor of "innovation", of "renovation" or of "revolution" on education when, in fact, in most times it serves to reinforce the most traditional pedagogical models. The modernity of new mediums does not guarantee anything. It happens because the medium is one variable among many others in the educational process; because the device itself does not guide to anything, except to the possibility of change ${ }^{3}$ (idem, p.123).

Jacquinot-Delaunay was graduated in Literary Studies and started teaching French and literature in a French public primary school class during the Sixties. At that time, she realized that her students were in 'another planet', as she mentioned in 2007 during an interview for the Comunicação \& Educação journal (Comunicação \& Educação. ECA-USP. Ano 12, n. 3 (set-dez. 2007), p. 73-80). Then she took part in a contest promoted by the School Television and, after winning, she started to work as educator and author-creator of pedagogical settings in TV shows (DALLA COSTA, 2007, p.73-74).

This experience drove her to her Doctoral studies at the École des

2 Original: Escolher uma pedagogia não é somente definir uma forma local de intervenção, é situarse na sociedade e na cultura, é, implícita ou explicitamente, tomar posição, fazer escolhas. Os problemas pedagógicos, como os outros, são, num determinado nível de análise, problemas políticos. 3 Original: Há uma real impostura ao sustentar-se que o audiovisual [leia-se digital, por exemplo, no lugar de audiovisual, nota das autoras] - como se diz - é um fator "de inovação", de "renovação" ou de "revolução" no ensino quando, na realidade, serve, na maioria das vezes, para reforçar os modelos pedagógicos mais tradicionais. A modernidade dos suportes não garante nada. Porque o medium é uma variável entre muitos outros no processo educativo; porque a ferramenta em si mesmo não conduz a nada, senão a uma possibilidade de mudança. 
Hautes Études en Sciences Sociales, under Christian Metz's supervision. In 1969 she was invited by the founders of the new University Paris 8 - Vincennes, which was created as a result of the events in 1968 - to teach at the Department of Sciences of Education. There, she studied the communication-education interface, questioning methodologies and proposing analysis for the use of technology at school. She advised thesis of Education Sciences, and after 1995 of Information and Communication Sciences. She was able to perfectly dialog in both areas (cf. JACQUINOT-DEALUNAY, 2006b), and, she knew how to relate them as no one else.

Her interest for technology also drove her to make researches in the field of distance learning, especially in what refers to pedagogical mediation. She wrote several articles and books about it, such as the text Absence and presence in pedagogical mediation: "Rien ne vaut la chaleur de la présence humaine" (JACQUINOT-DELAUNAY, 2002), which inspired one of us to state what follows:

the transnational distance is not exclusive of the distance learning; it exists in all human relationships and, through a centennial historical praxis, it is particularly revealed in the classroom. Both the standard classroom (suffice to say a masterful class in an auditorium) and the virtual classroom (a lecture given through a synchronous or an asynchronous videoconference) (OLIVEIRA, 2015, p. 174). ${ }^{4}$

Her goal was to understand whether it would be possible to improve or upgrade the learning process through technologies which are more and more present within society, as the following quote states.

Thus, the point is not to know whether a media is more effective than another, but to understand which attributes of each medium are better to foster the educational process due to students' characteristics and considering the task to be accomplished. Such kind of investigation has only begun to be done now ${ }^{5}$ (JACQUINOT-DELAUNAY, 2006a [1977], p. 125).

Jacquinot-Delaunay passed away when she was fully living her

4 Original: A distância transacional não é exclusiva do ensino a distância; ela existe em todos os relacionamentos humanos e, por via de uma praxis histórica de centenas de anos, revela-se particularmente na sala de aula. Na sala de aula presencial (basta lembrar a aula magistral em auditório) e na sala de aula virtual (palestra em videoconferência síncrona ou assíncrona)

5 Original: Assim, à questão de se saber se este ou aquele meio é mais eficaz do que um outro, conviria substituir a seguinte questão: que atributos específicos de que medium são próprios para favorecer que processo de aprendizagem em função de que traços característicos do aluno e tendo em consideração a tarefa a cumprir. Investigações como estas começam apenas agora a fazer-se. 
academic life in December 2014. Her death left as orphans about twenty teacher-researchers, who were her former advisees. She also left a void in the intellectual French circle which used to treat her as a true lady of the Science of Education. Open-minded, especially to knowledge, she was always able to travel and write in partnership with her advisees and colleagues. She used to practice what her theoretical legacy expresses so well:

the traditional didactic model makes the didactic act an act of knowledge transmission constituted by someone who knows towards someone who does not know, according to a narrowly determined itinerary. The image, and namely the filmic image, is particularly suitable to serve another didactic modal - creative and not only structural - what makes the didactic act a process of meaning production $^{6}$ (idem, p. 18).

The texts presented here particularly deal with distance learning. Each author associates his own researches with Jacquinot-Delaunay's writings regarding the theme and allowing us to develop a deep thinking about the idea of distance, the available methodologies and even the representation that the distance learning students have about the education received. These approaches are described in Martine Vidal, Monique Grandbastien and Pierre Moeglin's editorial. The reading of each text will surely give rise to concerns in those who understand that it is necessary to question the use of technologies in education, just like Jacquinot-Delaunay did. In other words, Jacquinot-Delaunay keeps doing what she always did to produce knowledge - now through her writings -; provoke! What remain are her presence and her transmitted knowledge, always looking for new inventions.

\section{REFERENCES}

DALLA COSTA, Rosa Maria Cardoso. Entrevista com Geneviève Jacquinot Delaunay. Revista Comunicação \& Educação. São Paulo: ECA-USP. Ano 12, n. 3 (set - dez. 2007), p. 73-80.

6 Original: 0 modelo didático tradicional faz do ato didáctico um ato de transmissão de um saber constituído de alguém que sabe, em direção a alguém que não sabe, segundo um itinerário estreitamente balizado. A imagem, e nomeadamente a imagem filmica, é particularmente adequada para servir um outro modelo didáctico - gerativo e já não estrutural - o que faz do ato didáctico um processo de produção de sentido 
JACQUINOT-DELAUNAY, Geneviève. Entrevista à revista Comunicação \& Educação. São Paulo: ECA-USP. Ano 12, n. 3 (set - dez. 2007), p. 73-80.

JACQUINOT-DELAUNAY, Geneviève. Imagem e Pedagogia. Mangualde: Edições Pedago, 2006a. Tradução e Revisão Científica por Lia Oliveira. Original: Jacquinot, G. Image et Pédagogie. Paris: PUF, 1977.

JACQUINOT-DELAUNAY, Geneviève. As Ciências da Educação e as Ciências da Comunicação em Diálogo: a propósito dos media e das tecnologias educativas, 2006b. In J. PARASKEVA \& L. R. OLIVEIRA (Orgs.) Currículo e Tecnologia Educativa. volume 1. Mangualde: Edições Pedago. p. 123-141. Texto original em francês Disponível em https://www.cairn.info/revue-l-annee-sociologique-20012-page-391.htm. Acesso em 21 de novembro de 2016.

JACQUINOT-DELAUNAY, Geneviève. Absence et présence dans la médiation pédagogique ou comment faire circuler les signes de la présence. In: COOL, R. Guir. (ss dir de). Pédagogies en développement. Pratiquer les TICE, Former les enseignants et les formateurs à de nouveaux usages. Bruxelles: De Boeck. 2002. s/p.

JACQUINOT, Geneviève. On demande toujours des inventeurs,

Communications, 33, p. 5-23,1981. DOI: 10.3406/comm.1981.1492 JACQUINOT, Geneviève. Apprivoiser la distance et supprimer l'absence? Ou les défis de la formation à distance. Revue Française de Pédagogie, 102, janvierfévrier-mars. 1993. p. 55-67.

OLIVEIRA, Lia Raquel (2015). Rien ne vaut la chaleur de la présence humaine: encurtando a distância transacional. Educativa, Goiânia, v.18, n. 1 (2015) p. 168 188 Disponível em: http://dx.doi.org/10.18224/educ.v18.n1.2015.168-188.

OLIVEIRA, Lia Raquel. Mediação docente e distância transacional: uso do Facebook num mestrado em regime misto (b-learning). Texto apresentado oralmente no congresso ENDIPE 2016 e em fase de submissão a uma revista.

TARDY, Michel. Le professeur et les images. Paris: PUF, 1966. Edição em língua portuguesa: O Professor e as Imagens, 1976, Cultrix. 


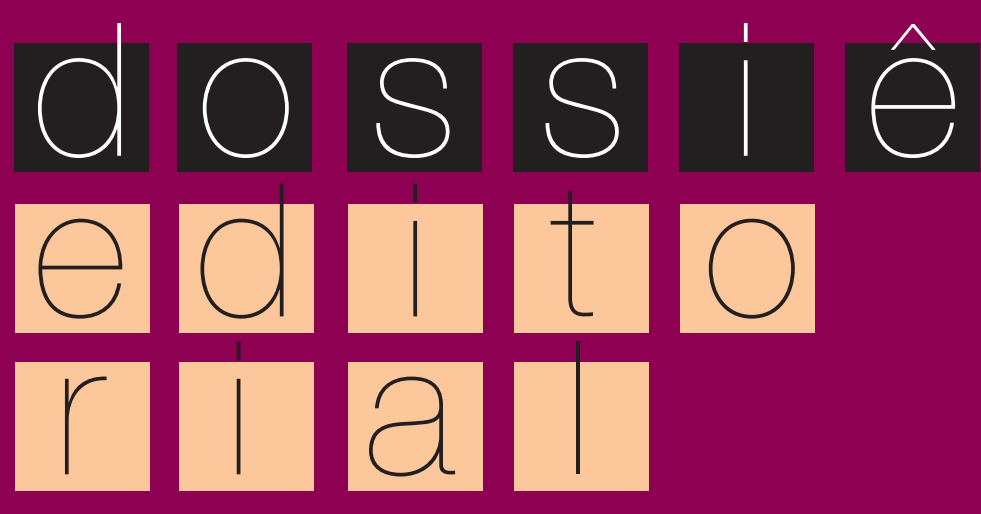


Editorial. Revista "Distances et Médiations des Savoirs".

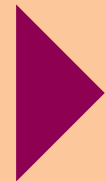




\section{Editorial do Dossiê $\hat{e}^{*}$}

MARTINE VIDAL

MONIQUE GRANDBASTIEN

PIERRE MOEGLIN

No termo de um longo, corajoso e assustador combate contra a doença, Geneviève Jacquinot-Delaunay acaba de apagar-se. Distances et Médiations des Savoirs perde uma amiga fiel, atenta e generosa, contribuidora desde os primeiros dias. Membro do nosso comitê de redação desde o tempo de Distances et Savoirs, ela era a nossa inspiradora e uma aliada preciosa ao serviço do projeto que está na origem desta revista: reforçar e melhor dar a conhecer e reconhecer a comunidade científica que, à escala internacional, trabalha sobre os problemas e desafios da formação a distância. Desta comunidade ela foi aliás uma figura maior, apesar dos seus centros de interesse terem largamente excedido as questões do acesso aos saberes a distância. Com efeito, ela era uma especialista reconhecida da semiologia da imagem e da tecnologia educativa, e os seus questionamentos regularmente renovados até ao fim interessavam a vários domínios situados fora do campo de Distances et Médiations des Savoirs. Debruçavam-se, nomeadamente, sobre a educação para os media e sobre os processos cognitivos e metacognitivos implicados na aprendizagem através dos media.

\footnotetext{
* Tradução de Lia Raquel Oliveira e Rosa Maria Cardoso Dalla Costa.
} 
A sua audiência era tão grande no estrangeiro como em França, tão forte junto dos práticos como dos investigadores. É disso testemunho a diversidade geográfica daquelas e daqueles que realizaram teses sob a sua orientação, o número e variedade das suas publicações, as múltiplas missões que efetuou em África, na Ámérica do Norte e do Sul, a sua audiência tanto em Ciências da Informação e Comunicação como em Ciências da Educação (JACQUINOT-DELAUNAY, 2004), nos círculos acadêmicos como nos meios da formação permanente e junto dos profissionais da televisão educativa. E é também significativo o fato, oportunamente lembrado por Laurent Petit numa leitura crítica (em http://dms.revues.org/783) redigida para o número precedente de DMS a propósito da publicação em 2012 da versão revista e aumentada de Image et Pédagogie, uma das suas duas ou três obras emblemáticas: em 1977, o seu lançamento recebe um acolhimento extraordinariamente favorável, do qual fazem eco jornais e revistas tão diferentes como Formation et Communication, L'Éducation, Le Monde de l'Éducation, Educational Broadcasting International, Média, Trait d'union des collèges et de leurs amis, Éducation enfantine, Bulletin critique du Livre français, Le journal des instituteurs, Audiovisuels et Communication Digest, La presse du cinéma. Image et son, Sonovision et même Balaventures, revista dos professores de francês no Uruguai. Em todo o lado, é sublinhado "o caráter (i)novador de uma abordagem metodológica saída de uma ciência qualificada na altura como 'nova' - a semiologia - abrindo um novo campo de investigação afirmado prometedor, o da semiologia da didática". E Laurent Petit acrescentando que "se o método semiológico se inscreve nos terrenos abertos por Christian Metz e Umberto Eco, poucos semiólogos se aventuraram no terreno da didática que Geneviève Jacquinot toma numa acepção larga do que é 'próprio para instruir"'.

Também não é um acaso que, resultante do seu excelente conhecimento do estado da arte e dos seus suportes en França e fora dela, ela tenha aceite prontamente encarregar-se, a nosso pedido, de um estudo que se revelará muito esclarecedor para o posicionamento de Distances et Savoirs, sobre as respetivas orientações das principais revistas no domínio. Deste estudo, apresentado ao nosso comité em 27 de março de 2002, ela retira um texto breve consagrado às revistas canadianas francófonas que tivemos a alegria e o orgulho de publicar no nosso primeiro número (JACQUINOT-DELAUNAY, 2003). 
A voz calorosa, alegre e grave de Geneviève continuará, por muito tempo, a fazer-se ouvir e a provocar-nos. "Provocar, diz ela": durante a preparação deste número, este título com acentos durassianos impôs-se-nos. Trata-se de uma questão de voz no "provocar", de uma voz que inspira e estimula, lança a dúvida e desafia, convida a responder e obriga a comprometer-se. É desta provocação que, militante e investigadora, observadora e atora, Geneviève foi portadora e da qual nós desejamos dar conta tão depressa quanto possível com este número.

Aliás, é notável a maneira como este número foi concebido e realizado: em pouco menos de um mês, portanto, com prazos extraordinariamente curtos, graças à contribuição espontânea de alguns e algumas que foram próximos dela, que com ela aprenderam muito, que lhe devem imenso e que, através das suas próprias produções, fizeram questão de trazer para aqui uma prova da fecundidade das suas. Outros textos, que se alimentam claramente dos trabalhos de Geneviève continuam a chegar-nos; na medida do possível, serão publicados nos números seguintes.

No momento em que os comprometíamos com a preparação deste número, sabíamos que Geneviève estava muito doente. Esperávamos, contudo, que ela tivesse a possibilidade de o conhecer. Leu os resumos, efetivamente, mas partiu quando as contribuições estavam ainda em avaliação. Apesar de tudo, terá tido o tempo necessário para agradecer a "todos e cada um" por este número. Mas não deveremos antes ser nós a agradecer-lhe?

Em jeito de agradecimento, poder-se-á encontrar aqui sete artigos científicos, assim como um retorno de experiência de uma das suas antigas doutorandas, a evocação de uma entrevista filmada, realizada em 2006 por Françoise Thibault e Jacques Wallet, disponível na Web e, para terminar, um pequeno léxico de palavras e imagens composto por Martine Vidal e Jacques Wallet. Em todas estas contribuições é a voz provocante de Geneviève que reconheceremos.

$\mathrm{O}$ artigo de Daniel Peraya estabelece dois momentos decisivos na sua reflexão sobre a formação a distância: o primeiro procede da problemática elaborada por Geneviève Jacquinot (1993) a propósito da comunicação educativa mediatizada; o segundo, em 2011, devese a dois números temáticos de Distances et Savoirs. Do primeiro aos segundos uma única e mesma questão: onde vai a distância? Lendo Daniel Peraya, vemos esboçar-se uma resposta cada vez mais consis- 
tente: não mais pensar a formação a distância do ponto de vista da distância mas do ponto de vista da presença et do signos, inclusivé na distância. Magnífica reviravolta de perspetiva! A Geneviève devemos aliás também muitos outros avanços teóricos do mesmo tipo. Por exemplo, como lembra justamente Geneviève Lameul, o seu contributo para a investigação é considerável quando formula, em 2001 com Hughes Choplin, os princípios de uma "abordagem dispositivo" visando articular os dois fenómenos, dispositivo e inovação. Com isso, propõe ver no dispositivo um dos objetos da negociação constitutiva de toda a aprendizagem e, simultaneamente, um dos pontos de cristalização da própria inovação pedagógica. Com a "investigação -inovação", acrescenta igualmente uma abordagem pioneira e de um grande interesse heurístico à panóplia das que visam tornar inteligível a complexidade social crescente das situações de aprendizagem.

Alguns dentre nós conheceram-na a partir do número 33 da prestigiosa revista Communications que coordena em 1981 e, mais particularmente, do artigo que nele publica: "On demande toujours des inventeurs.... O que há então de essencial neste artigo pleno de questionamentos, referências, intuições e análises que justifique que, hoje ainda, ele seja frequentemente citado? A esta interrogação, JeanFrançois Cerisier responde em substância que o mérito de Geneviève Jacquinot é o de aí ter pensado magistralmente a diferença entre invenção e inovação. Com efeito, ela interroga-se muito astuciosamente sobre a maneira de fazer novo com o velho, em vez de fazer velho com o novo. Formula também a questão tão simples e determinante de saber porquê "as pessoas" aprendem massivamente os media e de que modo (como) os aprendem. Um dos elementos da sua resposta deve ser procurado no princípio seguinte: "É preciso sair do primado do verbal sobre a pedagogia e interrogar-se adiante sobre os processos de aprendizagem nas suas relações com as diversas linguagens e não apenas com a linguagem verbal" (JACQUINOT, 1981, p. 14).

Viviane Glikman serve-se também dos trabalhos de Geneviève Jacquinot para constatar que são ainda raras as investigações que se debruçam sobre os públicos das formações a distância. Em particular, remete implicitamente para o seu artigo (JACQUINOT, 1999) sobre os "utilizadores que visamos nas nossas cabeças", e apresenta vários exemplos mostrando de que maneira, apoiando-nos nas reações dos aprendentes a distância, podemos projetar iluminações interessantes sobre a diversidade das práticas, das atitudes e mesmo das 
representações destes públicos. Acrescenta porém, que a dificuldade reside no facto de os públicos em questão não se deixarem fechar em tipologias acabadas. Pelo contrário, são ativos, adaptam as produções às suas expectativas e, desde que o dispositivo o permita, constroem por e para eles próprios o sentido das informações que lhes são transmitidas e das quais se apropriam. Desde logo, convém ao observador romper com a separação emissor/recetor própria da economia habitual dos meios de massas. Mas, para que o dispositivo permita esta rutura, é necessário que estratégias construtivistas sejam usadas. Ora, o contributo dos trabalhos de Geneviève Jacquinot, de acordo com Jean-Pierre Meunier, é precisamente o de sublinhar que, na programação de uma rede televisual comunitária como a "Canal Emploi" em Liège, uma outra relação dos adultos com os media é possível a partir do momento em que essas emissões adotam a linguagem audiovisual orientada para a abertura, ambivalência e negociação de sentido que quebre os códigos habituais do espetáculo televisual.

A situação é assim tão diferente nos MOOC? Lendo o artigo de Alain Jaillet, podemos ser tentados a responder negativamente a esta questão. Mais concretamente e segundo este autor, se os MOOC dão a impressão de contribuir para uma renovação da utilização dos filmes para fins de ensino, na realidade, eles não mais fazem do que "reinstalar o filme como instrumento pedagógico". De facto, continua, "Se a produção institucional de filmes profissionais, pedagógicos segundo os cânones da profissão, caiu quase a zero, a oferta de filmes com intenção de aprendizagem explodiu”. Tratar-se-á ainda de filmes? Sim, responde, porque muitas destas produções respondem, em certa medida, à exigência que Geneviève Jacquinot observou e analizou nas produções pedagógicas profissionais, de relacionar o mundo da escola com o mundo do especialista e com o mundo do assunto tratado.

Este relacionamento dos três mundos é suficiente para conferir a estas produções a sua dimensão pedagógica? Seguindo os passos de Geneviève Jacquinot, Patrick Guillemet responde pela negativa. Segundo o autor, ainda falta que os atores da formação a distância saibam escutar as "vozes da distância". Ou seja, no caso concreto, que os concetores e especialistas da TéléUniversité do Quebeque tomem o tempo de ouvir e de interpretar o que dizem os estudantes, por vezes de forma confusa numa página do Facebook por eles criada, sobre os problemas com que se defrontam no quotidiano. E que estes mesmos 
concetores compreendam, por exemplo, que acontece estes estudantes sentirem-se condenados a um autonomia que se assemelha para eles à da solidão, tão propícia esta ao puro e simples abandono.

Dar a palavra aos estudantes é também um dos princípios que Lia Raquel Oliveira reteve dos ensinamentos de Geneviève Jacquinot quando preparava a sua tese de doutoramento sob a sua orientação. Mostra aqui como o colocou em prática, na sua universidade, em Portugal, ao convidar 115 estudantes a produzirem autobiografias de um minuto, filmadas e disponibilizadas em vodcast. A experiência foi concludente, diz-nos, tanto no que concerne à consecução dos objetivos de multiliteracia a que se tinha proposto como no respeitante à satisfação dos interessados.

$\mathrm{Da}$ fecundidade do percurso de Geneviève Jacquinot cada um poderá julgar por si mesmo. Bastar-lhe-á para tanto ler a transcrição da longa entrevista filmada por Françoise Thibault e Jacques Wallet, em outubro de 2006. Igual a si própria, modesta e estimulante, conta-nos com palavras simples as circunstâncias que lhe valeram fazer grandes coisas. E de como fez evoluir os seus questionamentos, de terreno em terreno, conservando sempre as suas orientações e preocupações originais. Lição de vida excecional durante a qual, como bem diz Françoise Thibault, investigação e comprometimento estão intimamente ligados.

Excecional lição de otimismo e de bom humor, igualmente, justifica a homenagem final sob a forma de um piscar de olho que lhe enviam Martine Vidal e Jacques Wallet. Escolhem quatro imagens do aprendente que, falando por si próprias, aqui são associadas a uma dezena de citações emprestadas de Geneviève, dando-lhes uma singular mise en perspective. Maneira de lembrar, também, que esta grande profissional da investigação e da intervenção pedagógica tão bem sabia não se levar a sério...

O conjunto não estaria completo sem as nossas rúbricas habituais; a rica discussão sobre a questão dos MOOC que tínhamos iniciado no no 5 fecha-se com este na contribuição de Mathieu Cisel cuja tese, em que trabalha atualmente sob a orientação de Éric Bruillard, se debruça sobre esta questão e se alimenta da sua implicação na plataforma Fun. Contudo, a nota de leitura "Para descobrir os MOOC", redigida por Monique Grandbastien sobre a obra que acaba de ser lançada de Jean-Charles Pomerol, Yves Epelboin e Claire Thoury, Les 
MOOC. Conception, usages et modèles économiques, prolonga um pouco mais esta reflexão e cruzamento de olhares para os quais, nos seus quatro últimos números, a DMS se orgulha de ter contribuído.

\section{REFERÊNCIAS $^{1}$}

JACQUINOT, Geneviève. Image et pédagogie. Analyse sémiologique du film à intention didactique. Paris, Puf. ${ }^{2}, 1977$.

JACQUINOT, Geneviève. " On demande toujours des inventeurs... ", In: Communications $\mathrm{n}^{\circ}$ 33, Apprendre des médias, p. 5-23, 1977.

JACQUINOT, Geneviève. La Communication éducative médiatisée: de l'âge de pierre à l'âge de bronze. In: Études de communication, n ${ }^{\circ}$, pp. 77-90, 1933.

JACQUINOT, Geneviève. Qui sont ces usagers qu'on cible dans nos têtes ?. (Org.) GLIKMAN, Viviane. In: Formations ouvertes et à distance : le point de vue des usagers. Journée détude du 28 novembre 1997, Paris, INRP, pp. 21-35, 1999.

JACQUINOT-DELAUNAY, Geneviève. Notre champ: du côté des revues francophones. In: Distances et Savoirs, vol. 1 n 1, pp. 167-170, 2003.

JACQUINOT-DELAUNAY, Geneviève. Sic et Sed sont dans un bateau..., In: Hermès La Revue, n 38, p. 198. ${ }^{3}, 2004$.

JACQUINOT, Geneviève; CHOPLIN, Hugues. La démarche dispositive aux risques de l'innovation, In: Éducation Permanente, $\mathrm{n}^{\circ}$ 152: Les TIC au service des nouveaux dispositifs de formation, pp185-198, 2002.

PETIT, Laurent. Geneviève Jacquinot, "Image et pédagogie” revisité, In:

Distances et médiations des savoirs, $\mathrm{n}^{\circ}$ 7, 2014. [Acessado em: 6 outubro 2014]. Disponível em: http://dms.revues.org/783

1 Nota da revisão: “Para esta publicação, aproximamos devidamente os textos aqui selecionados às normas da $\mathrm{ABNT}$, tendo, no entanto, respeitado a versão original das referências compreendidas pelas normas acadêmicas francesas."

2 Nota das tradutoras: a obra foi traduzida para português: JACQUINOT-DELAUNAY, Geneviève (2006) Imagem e Pedagogia. Mangualde: Edições Pedago. Trad. e Revisão Científica por Lia Oliveira. 3 Nota das tradutoras: pode ser encontrada uma versão portuguesa deste texto em JACQUINOTDELAUNAY, G. (2006). As Ciências da Educação e as Ciências da Comunicação em Diálogo: a propósito dos media e das tecnologias educativas. In J. Paraskeva e Lia Oliveira (Eds.) Currículo e Tecnologia Educativa. Volume 1. Mangualde: Edições Pedago. Pp. 123-141. 


\section{Ficha técnica da edição francesa}

Tradução autorizada da revista francesa Distances et Médiations des Savoirs (http://dms.revues.org/ e número traduzido: https://dms.revues.org/864)

Diretor da publicação: Serge Bergamelli.

Editor: Centre National d'Enseignement à Distance.

Política de edição eletrônica: Publication Intégrale en Open Access Freemium.

Periodicidade: trimestral.

Ano de criação: 2012.

Responsável da edição: Martine Vidal

Publicação online: Alina Zaharia, Cléo/OpenEdition (vol. $1 / \mathrm{n}^{\circ} 1$ ).

Acompanhamento editorial: Bastien Miraucourt, Cléo/OpenEdition.

Realização da maqueta: Lisa George, Cléo/OpenEdition.

Integração da maqueta: Pierre André, Cléo/OpenEdition.

\section{Avertissement:}

Le contenu de ce site relève de la législation française sur la propriété intelectuelle et est la propriété exclusive de l'éditeur. Les oeuvres figurant sur ce site peuvent être consultées et reproduites sur un support papier ou numérique sous réserve quelles soient strictement réservées à un usage soit personnel, soit scientifique ou pédagogique excluant toute exploitation commerciale. La reproduction devra obligatoirement mentionner léditeur, le nom de la revue, lauteur et la référence du document. Toute autre reproduction est interdite sauf accord préalable de léditeur, en dehors des cas prévus para la législation en vigueur en France.

\section{Revues.org}

Est un portail de revues en sciences humaines et sociales développé par le Cléo, Centre pour lédition électronique ouverte (CNRS, EHESS, UAPV)

$h t t p: / /$ dms.revues.org

http://www.revues.org

\section{Document accessible en ligne sur:}

http://dms.revues.org/950 